\title{
Extent of Availability of Safety I nstruments/ Equipment in Science Laboratories in Secondary Schools in Ebonyi State of Nigeria
}

\author{
Celestine N. Nwele \\ Department of Chemistry \\ Ebonyi State College Of Education, Ikwo-Nigeria
}

Doi:10.5901/ ajis.2013.v2n10p131

\begin{abstract}
The study examined the extent of availability of safety instruments in science laboratories in secondary schools in Ebonyi State of Nigeria. The researcher used 45 secondary schools and 180 science teachers and laboratory attendants for the study. Descriptive survey design was adopted. 11-item four-point scale structured questionnaire was used to collect data. The data collected were analysed using mean and standard deviation for the research question while t-test was used to test the hypothesis at 0.05 alpha level of significance. Result of the data analysis revealed that the extent of availability of safety instruments is very low in secondary schools in Ebonyi state of Nigeria. The implication of this is that sustainable development of science laboratory skills in the state will be hampered. The researcher recommends that the government of Ebonyi State should ensure that safety instruments are provided to a very high extent in secondary schools in the state.
\end{abstract}

Keywords: Safety instrument, Science Laboratory, Availability, Laboratory Skill, Accident.

\section{Introduction}

Science is a study of nature and natural phenomenon. Mbajiorgu, (2003) stated that this study of nature and natural phenomenon relies on hypothetical-deductive experimental approach and operates on physical, measurable and observable realm. The study of science involves a systematic process of investigation that employs observation and experimentation as tools (Okeke, 2007). The field of investigation in science according to Mbajiorgu, (2003) and Igwe, (2003) is the natural environment and may involve going outside the classroom to look at flowers, insects, rocks rivers, sky, or activities (experiments) in the formal school science laboratories.

A great deal of importance is attached to science and technology education for Nigeria to achieve accelerated national development. FRN, (2004) stipulates a ratio of 6:4 of science and technology to art courses in admission of students in tertiary institutions in the country. Nwana, Baja and Obioha, (2000) opined that without science education, it is impossible to develop such professions as agriculture, dentistry, medicine, engineering, astronomy, space exploration, geology, pharmacy. To accelerate national development, a method of teaching science which ensures a high degree of student's participation is advocated. Adigun, (1999) emphasized that students have to be actively involved in the science and technology lessons to acquire skills in their various field of study. These science lessons (activities) take place in normal school science laboratories. These laboratory activities are usually prone to risks, hazards, and accidents, hence the need to provide safety instruments/equipments in the laboratories.

Laboratory activities or experiments are very important and essential in the teaching and learning of science in secondary schools. The laboratory activities are carried out using materials and equipment and following laid down procedures that require care and precaution, (Nwanuma 2005). Ali (1998:84) defined laboratory as a "place where experiments in science are carried out 
with chemicals, specimens, materials and equipment" According to Ibiam and Idoko, (2008), laboratories are most often prone to hazards due to the presence of dangerous chemicals and equipment not carefully handled by the users. Igwe, (2003) reported that cases of accidents abound during experiments in secondary school science laboratories in Nigeria. Nkwegu, (2008) outlined causes of accidents in the laboratory to include carelessness, improper storage of materials and equipment, ignorance of the use of protective items for safety. Adigun (1999) reported that most fatal accidents in the history of scientific and technological development occurred as a result of hazards associated with experiments being carried out, ignorance of necessary precautionary measures and lack of safety instruments and skill in their operations.

Aniodoh, (2001), Ezeliora, (2001) and Igwe, (2003) stressed that safety instruments such as fire extinguishers, first aid box, hand gloves, fume cupboards, laboratory coats, fire blankets, gas masks, eyewashers, acid cabinets, safety glasses, face shields, protective foot wear, respirators should be available in science laboratories. These are used to prevent and control accidents and emergency situations in the laboratories. Archenhold, Jenkins and Robinson, (1978) and Ezeliora, (2001) emphasized that students should know the locations and how to use these instruments in the laboratory.

Science laboratories appear to be most prone to risks, hazards and accidents because of the presence of dangerous chemicals in them. The science laboratory of I kwo high School of Ebonyi State was once partially burnt because of carelessness and improper lighting of the Bunsen burner and absence of a functioning fire extinguishers and fire blankets to quench the fire, (Nwanuma, 2005). According to Nkwegu, (2008), students of Community School Ekpomaka also in Ebonyi State in similar vein carry out experiments in the science laboratory without wearing laboratory coats, safety goggles and hand gloves. It appears that there are no safety instruments such as fume cupboards, fire blankets, spill kits, vacuum desiccators, gas mask in most of the laboratories in the state. The first aid boxes available in some of laboratories appear to be worn out with no functioning materials in them. The carbon dioxide fire extinguishers available in some of the laboratories seem to be empty of the gas. It is possible that students and teachers in some of the laboratories carry out experiments without wearing laboratory coats, hand gloves or safety goggles.

These presumptions all point to fact that science laboratories in secondary school in Ebonyi State may not have safety instruments to a desirable extent. The users of these laboratories, materials in the laboratories and the laboratories themselves could therefore be exposed to the danger, risks and accidents. This has the grave implication of hampering the sustainable development of science laboratory skills. It is uncertain whether there are empirical data on the extent of availability of safety instruments/equipment in science laboratories in secondary schools in Ebonyi State. It is in the light of this, that this research is set out to assess the extent of availability of safety instruments in science laboratories in secondary schools in Ebonyi State of Nigeria.

\section{Statement of the Problem}

Material Safety Data Sheet (MSDS), a document on safety handling of various laboratories materials, contain a wealth of information on flammability, poison nature of each chemical, health hazard, safety instruments needed, first aids and other precautionary measures required in science laboratories. It is uncertain the extent to which requisite safety instruments/equipment necessary to prevent and control accidents are available in secondary school science laboratories in Ebonyi State of Nigeria. Thus, this study is designed to assess the extent of availability of safety instruments/equipment in secondary school science laboratories in Ebonyi State of Nigeria.

\section{Purpose of the Study}

The study is designed to investigate the extent of availability of safety instruments/equipment in 
science laboratories in secondary schools in Ebonyi State of Nigeria.

\section{Research Question}

To guide the study, the following research question was posed:

To what extent are safety instruments/equipment available in science laboratories in secondary schools in Ebonyi State?

\section{Hypothesis}

There is no significant difference in the mean responses of science teachers and laboratory attendants on the extent of availability of safety instruments/equipment in science laboratories in secondary schools in Ebonyi State of Nigeria.

\section{Methodology}

The study was a descriptive survey, which sought to ascertain the mean responses of science teachers and laboratory attendants on the extent of availability of safety instruments/equipment in secondary school science laboratories in Ebonyi State of Nigeria. The study was carried out in the three education zones of Ebonyi State. The zones are Abakaliki, Onueke and Afikpo. The population of the study consisted of senior secondary school science teachers and laboratory attendants in 213 government owned secondary schools in Ebonyi State. Stratified random sampling was used to select 15 secondary schools from each of the three education zones in the State. Purposive random sampling technique was used to select 135 science teachers and 45 laboratory attendants. The use of purposive sampling technique was to ensure that science teachers and laboratory attendants who are most experienced in laboratory activities and thus are most likely to know the requisite safety instruments in science laboratories, were used for the study.

The instrument for data collection was a four-point scale structured questionnaire developed by the researcher. The weighting of the responses was: very high extent $\mathrm{VHE}=4$, high extent $\mathrm{HE}$ $=3$, low extent LE $=2$ and very low extent VLE $=1$. Three experts from Science Education Department, Ebonyi State University Abakaliki, validated the instruments. The researcher administered copies of the instrument to a sample of 15 science teachers and 15 laboratory attendants that were not part of the sample of the study. Cronbach alpha statistics was used to compute the reliability coefficient. A reliability coefficient of 0.80 was obtained indicating that the instrument was very reliable.

The researcher was assisted by two research assistants to distribute copies of the questionnaire. In this way, all the copies distributed were recovered. Mean and standard deviation were used in answering the research question while t-test was used to test the null hypothesis at 0.05 level of significance. A mean value of 1.00-1.49 was regarded as VLE, 1.50-2.49 as LE, 2.503.49 as HE and 3.50-4.00 as VHE.

\section{Results}

The results were presented according to the research question and the null hypothesis in table 1 and 2 respectively.

Table 1: mean result based on the extent of availability safety instruments.

\begin{tabular}{ccccccccc}
\hline S/N & Safety Instruments & VHE & HE & LE & VLE & $\bar{X}$ & SD & interpretation \\
\hline 1 & Fire extinguishers & 2 & 44 & 54 & 80 & 1.82 & 0.82 & LE \\
2 & First aid kits & 8 & 38 & 48 & 86 & 1.82 & 0.81 & LE \\
\hline
\end{tabular}




\begin{tabular}{clccccccc}
\hline 3 & Eye washers/Safety showers & 0 & 2 & 18 & 160 & 1.11 & 0.33 & VLE \\
4 & Fume Cupboard & 0 & 2 & 20 & 158 & 1.13 & 0.37 & VLE \\
5 & Acid cabinets & 8 & 38 & 48 & 86 & 1.82 & 0.81 & LE \\
6 & Fire blankets & 0 & 0 & 18 & 162 & 1.11 & 0.33 & VLE \\
7 & Safety goggles & 0 & 24 & 60 & 96 & 1.58 & 0.70 & LE \\
8 & Laboratory coats & 0 & 30 & 50 & 100 & 1.62 & 0.76 & LE \\
9 & Hand gloves & 18 & 20 & 46 & 96 & 1.78 & 1.00 & LE \\
10 & Gas masks & 0 & 2 & 22 & 156 & 1.15 & 0.43 & VLE \\
11 & Fire proof Cupboards & 1 & 1 & 10 & 168 & 1.08 & 0.34 & VLE \\
& Grand mean & & & & & 1.45 & 0.65 & VLE \\
\hline
\end{tabular}

Based on the result of data analysis shown in table 1, items 1, 2, 5, 7, 8 and 9 were available at a low extent (LE) while items 3, 4, 6, 10 and 11 are available at very low extent (VLE) in secondary schools in Ebonyi State. The grand mean of 1.45 and SD of 0.62 also show that the extent of availability of safety instruments in the laboratory is very low.

Table 2: t-test result based on extent of availability of safety instruments.

\begin{tabular}{clccccccc}
\hline SN & \multicolumn{1}{c}{ Variables } & No. & $\bar{X}$ & SD & DF & T-cal & T-crit & Decision \\
\hline 1 & Science Teachers & 135 & 1.87 & 100 & 178 & 0.30 & 1.96 & Accept \\
& Laboratory attendants & 45 & 1.87 & 100 & 178 & & & \\
2 & Science Teachers & 135 & 1.85 & 0.82 & 178 & 1.04 & 1.96 & Accept \\
& Laboratory attendants & 45 & 1.7 & 0.84 & 178 & & & \\
3 & Science Teachers & 135 & 1.14 & 0.37 & 178 & 2.63 & 1.96 & Reject \\
& Laboratory attendants & 45 & 1.00 & 0.00 & & & & \\
4 & Science Teachers & 135 & 1.17 & 0.42 & 178 & 2.83 & 1.96 & Reject \\
& Laboratory attendants & 45 & 1.00 & 0.00 & & & & \\
5 & Science Teachers & 135 & 1.84 & 0.82 & 178 & 1.03 & 1.96 & Accept \\
& Laboratory attendants & 45 & 1.71 & 0.83 & & & & \\
6 & Science Teachers & 135 & 1.89 & 0.94 & 178 & 1.89 & 1.96 & Accept \\
& Laboratory attendants & 45 & 1.60 & 0.80 & 178 & & & \\
7 & Science Teachers & 135 & 159 & 0.68 & 178 & 0.12 & 1.96 & Accept \\
& Laboratory attendants & 45 & 1.57 & 0.78 & & & & \\
8 & Science Teachers & 135 & 1.68 & 0.78 & 178 & 0.82 & 1.96 & Accept \\
& Laboratory attendants & 45 & 1.44 & 0.76 & & & & \\
9 & Science Teachers & 135 & 1.77 & 1.00 & 178 & 0.30 & 1.96 & Accept \\
& Laboratory attendants & 45 & 1.48 & 1.00 & & & & \\
10 & Science Teachers & 135 & 1.20 & 0.48 & 178 & 2.41 & 1.96 & Reject \\
& Laboratory attendants & 45 & 1.02 & 0.14 & & & & \\
11 & Science Teachers & 135 & 1.11 & 0.39 & 178 & 1.86 & 1.96 & Accept \\
& Laboratory attendants & 45 & 1.00 & 0.00 & & 1.65 & 1.96 & Accept \\
\hline & T-test value & & & & & & &
\end{tabular}

Summary of data analysis in table 2 indicates that Ho for items 1, 2, 5, 6, 7, 8, 9, and 11 were accepted because their t-calculated values were less than t-critical value of 1.96. Items 3,4 and 10 have t-calculated values greater than t-critical and were therefore rejected. The grand t-calculated value of 1.65 is less than t-critical of 1.96 . This means that Ho is accepted implying that the mean responses of science teachers and laboratory attendants do not differ significantly at 0.05 level of significance with respect to availability of safety instruments/equipment in the science laboratories. 


\section{Discussion}

Summary of the data analysis on table 1 indicates that the extent of availability of safety instruments in science laboratories in secondary schools in Ebonyi State of Nigeria is very low. The summary indicates that the extent of availability of safety showers/eye washers, fume cupboards, gas masks, fire blankets and fire proof cupboards is very low. On the other hand, the extent of availability of first aid kits, acid cabinets, safety goggles, laboratory coats and hand gloves is low in secondary school science laboratories in Ebonyi State of Nigeria. This result shows that most secondary school science laboratories in Ebonyi State do not have safety equipment to a desirable extent. The finding is in line with the finding of Adigun, (1999) that most science laboratories in secondary schools in Lagos State of Nigeria do not have adequate safety equipment. It is also in line with the finding of I biam, Ibrahim and Idoko, (2008) that there are inadequate safety gadgets and protective wears in science laboratories in secondary schools in Nsukka Local Government Area of Enugu State of Nigeria.

Result of t-test on the table 2 showed that t-value of 1.65 was obtained. This is less than tcritical of 1.96. $\mathrm{HO}$ is therefore accepted implying that the responses of science teachers and laboratory attendants do not differ significantly with respect to the availability safety instruments in the science laboratories in the secondary schools in Ebonyi State of Nigeria. The lack of significant difference in the mean responses could be explained by the fact that science teachers and laboratory attendants are both users of the laboratories. Both would therefore likely know whether any equipment is available or not and the extent of their availability.

\section{Conclusion and Recommendation}

Based on the result of the study, it was found that safety instruments/equipment are not available to a desirable extent in science laboratories in secondary schools in Ebonyi State of Nigeria. Some safety instruments are available at a very low extent (VLE) while others are available at low extent (LE).There is no safety instrument that is available at a high or very high extent. This situation makes the laboratory unsafe for users, materials in the laboratories and the laboratories themselves. The implication is that sustainable development of science laboratory skills will likely be hampered. The science graduates of the secondary schools will only know the theories without the accompanying practical skills. The researcher therefore recommends that the government of Ebonyi State should ensure that safety instruments are provided to a very high extend (VHE) in science laboratories in secondary school in the state. Science Teachers Association of Nigeria, (STAN) Ebonyi State chapter, should insist that necessary safety instruments/equipment are installed in the secondary school laboratories in the state. In this way, a good foundation for science laboratory activities devoid of fear, and engenders sustainable development of science laboratory skills by the students would be laid. This is a way of enhancing the development of a culture of scientific researches, which will in turn propel the sustainable technological development of the society

\section{References}

I biam J.M., I brahim M. and Idoko E.A., (2008). A survey of laboratory safety in secondary school in Nsukka Local Government Area. An unpublished B.Sc (Ed) project of the Department of Science Education, UNN.

Adigun, A.V., (1999). Evaluating adequacy of safety facilities in conducting secondary school technology and science practicals. $40^{\text {th }}$ Annual Conference Proceedings of Science Teacher Association of Nigeria. 202-265.

Ali A., (1999). Strategic issues and trend in Science education in Africa. Onitsha:Cape Publishers International Ltd. 
Aniodoh H.C.A., (2001). Modern aspect of Intergrated science Education. Enugu: Hacotan Education Books.

Archenhold W.F, Jenkins Edward And Wood Robinson, (1978). School science laboratories. A hand book on design, management and Organisation. London: John Murray Publishers Ltd.

Ezeliora, B., (2001). A guide to practical approach to laboratory management and safety precautions. Enugu: Snaap Press Ltd.

Federal Republic of Nigeria, (2004). National policy on education. Abuja: NERDC.

Igwe O.I., (2003). Principles of science and science teaching in Nigeria (an introduction). Enugu: Jones Communications Publishers.

Ikoku C.,Ahmed M. And Joju E., (1984). Laboratory exercises in Chemistry. Enugu Fourth Dimension publishers.

Mbajiorgu N.M., (2003). Science: The teachers perspective. (An introduction to science education). Enugu: Institute of Development studies UNN.

General Guidelines for science Safety, (2008). Wikipedia online encyclopaedia, retrieved March 5,2008 from www.sciencebyjones.con/safety rules.

National Commission for Colleges of Education, (2009). Minimum standard for Nigeria certificate in education. Abuja: NCCE.

Nkwegu V.N., (2008). Adequacy of safety measures in chemistry laboratories in secondary schools in Ikwo L.G.A of Ebonyi State: An unpublished NCE project of the department of chemistry Ebonyi State College Education, I kwo.

Nwanuma T.N., (2008), Laboratory safety awareness of secondary school students in Ikwo L.G.A. Ebonyi State. An unpublished NCE project of the Department of chemistry Ebonyi State college of Education I kwo.

Okeke E.A.C., (2005). Making science education accessible to all. $23^{\text {rd }}$ inaugural lecture of the University of Nigeria Nsukka: University of Nigeria Press Ltd. 